\title{
Environmental Awareness, Economic Orientation, and Farming Practices: A Comparison of Organic and Conventional Farmers
}

\section{ELIZABETH MCCANN}

University of Wisconsin-Stevens Point

University of Wisconsin Extension

College of Natural Resources

Stevens Point, Wisconsin 54481-3897, USA

\section{SHANNON SULLIVAN \\ DONNA ERICKSON* \\ RAYMOND DE YOUNG}

School of Natural Resources and Environment

University of Michigan

430 E. University Avenue

Ann Arbor, Michigan 48109-1115, USA

ABSTRACT / This study examines similarities and differences between organic and conventional farmers. We explore the factors that underlie farmers' conservation attitudes and behaviors, including demographic and farm characteristics, awareness of and concern for environmental prob- lems associated with agriculture, economic orientation toward farming, and self-reported conservation practices. A series of intensive personal interviews was conducted with 25 farmers in Washtenaw County, Michigan, USA, using both qualitative and quantitative survey methods. The findings indicate that both groups of farmers share a concern for the economic risks associated with farming, although the organic farmers reported a significantly greater concern for long-term sustainability and a greater willingness to incur present risk to gain future benefits. Organic farmers expressed a greater awareness of and concern for environmental problems associated with agriculture. Organic farmers also scored significantly higher on a multifaceted measure of conservation practices, although both groups had a fairly high adoption rate. Implications of these findings are discussed, relative to economic risks of farming, implications for new farmers, effectiveness of conservation education and government programs, and impact of farm size and crop diversity.
Farmers have been characterized as having ties to the land that give them a deep awareness of natural cycles, appreciation for natural beauty, and sense of responsibility as stewards. In contrast, their relationship to the land has been characterized as more utilitarian than others who are less directly dependent on its bounty. The view of farmers as people who, at the same time, care for and pollute the land is supported in the contemporary literature on the environmental attitudes of farmers (Westmacott 1983, Tremblay and Dunlap 1978). While assumptions are made about the environmental ethics of farmers, few studies have determined whether such an ethic exists. Because farmers are dependent on the land for their livelihood and are in close contact with the land on a daily basis, one might assume that they would perceive themselves as environmentally concerned and responsible. Previous studies, however, have been inconclusive regarding farmers' conservation atti-

KEY WORDS: Environmental attitudes; Conservation behaviors; Organic farming; Agricultural sustainability

*Author to whom correspondence should be addressed. tudes. Moreover, the link between conser vation attitude and behavior is itself uncertain.

This study examines similarities and differences between organic and conventional farmers in order to understand the factors that underlie their conservation attitudes and behaviors. The literature on adoption of conservation practices is reviewed, followed by a description of the survey instrument used for this research. Findings are discussed according to four factors: (1) demographic and farm characteristics; (2) awareness of and concern for environmental problems associated with agriculture; (3) economic orientation toward farming; and (4) self-reported agricultural practices.

\section{Adoption of Conservation Practices}

Previous work has shown that, at least in general terms, farmers are concerned about the adverse effects of farming on the environment. Most British farmers interviewed by Carr and Tait (1991) had favorable attitudes toward conservation in general terms. While Buttel and others ( 1981) found conventional farmers to be less concerned about agricultural chemical pollution than alternative farmers, Anderson's (1990) research 
revealed that conventional farmers are deeply concerned about the effects of groundwater pollution on their families' health. Buttel and others (1981) observed that concern with agricultural chemical pollution and concern with soil erosion are independent. Consequently, "agrarian environmentalism" is not a singular construct or dimension.

Several models in use, to predict which farmers tend to use and adopt conservation practices (Lockeretz 1992, N owak 1992, Napier and others 1988a,b), can be grouped around three paradigms; (1) sociodemographic models, (2) farm structure models, and (3) diffusion models. The sociodemographic model adopts demographic variables, such as age and education, to explain differences in farmers' attitudes and practices (Rogers 1983). For example, in surveys of N orth Dakota farm operators, Sell and others (1991) and Jacobsen and others (1991) found that farmers attempting sustainable practices were younger than their conventional counterparts. In studies of I owa farm operators, Bultena and others (1981) and Bultena and Hoiberg (1983) concluded that older farmers displayed more cautious attitudes toward land-use planning and the adoption of conservation tillage than younger farmers. Other research has indicated that age and farming experience have no influence on a farmer's predisposition toward adoption of new conservation practices ( $\mathrm{Napier}$ and Forster 1982). Anderson (1990) found that alternative farmers had less farming experience than conventional farmers. Bultena and others (1981) observed that historically these variables have not been good predictors of adoption of soil erosion control practices and found that land-use attitudes were similarly independent of farmers' social and economic profiles. Similar inconsistencies exist among researchers' findings regarding the influence of education on farmers' behavior and environmental attitudes (Christensen and Norris 1983, Anderson 1990, Buttel and others 1981).

The farm structure paradigm assumes that farm characteristics, such as size, type, or income, are the primary determinants of the adoption of conservation behavior. Miranowski (1982) found a positive correlation between larger farm size and adoption of conservation practices. An alternative theory suggests that higher debt burdens combined with a largely economic orientation toward agriculture make large farms less likely to adopt practices that protect the environment (Buttel and others 1981). Anderson (1990) found that alternative farmers tend to have much smaller farms than conventional farmers, while Dick (1992) found that higher income farmers simultaneously used more chemicals and more al ternative practices. The importance of economics in farmers' decisions has been documented
(Napier and others 1988a,b), although Buttel and others (1981) concluded that a noneconomic orientation toward agriculture is an important antecedent of concern with soil erosion. None of the farmers surveyed by Duff and others (1991) listed financial considerations as an obstacle to the adoption and use of soil conservation practices.

Reports on the relationships between production type and conser vation behavior and attitudes are slightly more consistent. The survey by Sell and others (1991) of North Dakota farmers found sustainable farms were more diversified than conventional farms. O bservations indicate that cash grain farms use few conservation practices because of their emphasis on short-term profits (Christensen and Norris 1983). In addition, research has shown that a positive correlation exists between land tenure and conservation practices. The study of Duff and others (1991) revealed that soil conservation practices are used with less frequency and intensity on rented land, and Anderson (1990) found that alternative farmers own more of the land they operate. Another study, which classified farm tenure types as individual, family, corporate, or partnership, found no correlation between farm type and the perceived need or actual use of conservation practices (H oover and O scar 1980).

The diffusion model contends that adoption of conservation practices is based principally upon information and past experiences and that the adopted practices will have immediate benefit to the adopter. Some sociodemographic variables such as age, education, years of farming, and awareness and perceived relevance of conser vation issues and practices are used as measures in this model. Napier and others (1988b) observed that awareness of problems such as soil erosion is related to the ad option of conser vation practices. H owever, other observations also identified a discrepancy between farmers' perception of environmental problems and conservation practices on their farmsand the actual severity of the environmental problems and intensity of practices to address them. Farmers consistently underestimate the severity of specific environmental problems on their own land (Bruening and Rollins 1990, Napier and others 1988a, Napier and Camboni 1988).

Aside from predicting conservation behavior according to the models shown above, another challenge is to determine which farmers are actually practicing conservation management. This involves categorizing types of farm operations according to some type of conser vation index. Since the dustbowl of the 1930s, researchers have continually developed techniques to mitigate agriculture's impact on the environment. Social science re- 
searchers have used these practices as measures of adoption rates and conservation orientation ( Lockeretz 1988, Schaefer 1989, National Research Council 1989). These measures have focused on both physical and chemical soil conservation practices such as use of conservation tillage, cover crops, waterway systems, terraces, windbreaks, strip-cropping and contour farming, and retirement of erosion-prone land ( $\mathrm{N}$ apier and Camboni 1988, Napier and others 1988b, Bruening and Rollins 1990, Esseks and others 1990, Dick 1992, Anderson 1990). In a study to determine if various methods of classifying farmers as conventional or sustainable are interchangeable, Youngs and others (1991) measured use of synthetic agricultural chemicals and no-till farming. Dick (1992) measured sustainability using decreased use of agrochemical inputs and use of minimum tillage, rotation with a legume, and nitrogen budgeting. Interestingly, these researchers have concluded that chemical input use and production practices do not measure the same phenomenon. In her study of organic and conventional farmers, to corroborate these findings, Anderson (1990) reported that conventional farmers use many of the same management techniques as organic farmers, including crop rotations, cover crops, insect and disease-resistant varieties, and mechanical cultivation.

We developed and implemented a survey instrument for testing several concepts reviewed above. Our initial hypotheses were that:

1. Organic and conventional farmers differ in their demographic characteristics and in the structure of their farms.

2. Conventional farmers have a more economic orientation toward agriculture and are less willing to take economic risks than organic farmers.

3. Organic farmers have a greater awareness of and concern for environmental problems associated with agriculture than conventional farmers.

4. Conventional farmers use conservation practices with less frequency than organic farmers.

\section{Methods}

The research sample was drawn from two separate sources in and around Washtenaw County, Michigan, USA (Figure 1). This area is historically an agricultural community where the predominant farm commodities have been livestock and grain crops. However, the productive soils and conducive climate permit a wide variety of crops. The first source was a list of approximately 800 farmers obtained from the Washtenaw County office of the Natural Resource Conservation Service (formerly Soil Conservation Service). This list

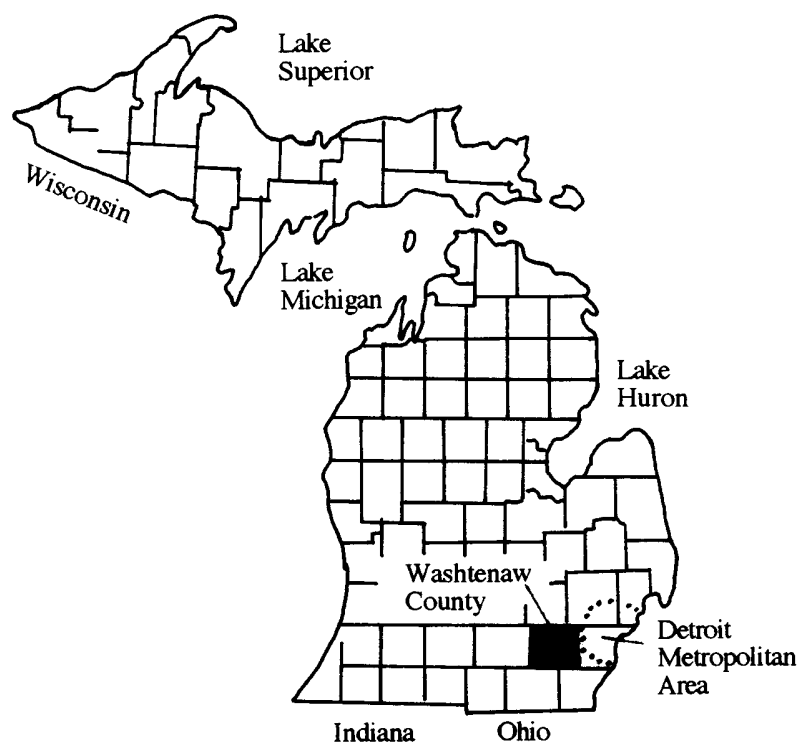

Figure 1. Location of Washtenaw County in state of Michigan, USA.

included all those individuals who were farm owners and/ or farm operators in the county. For the purposes of this study these individuals were considered to be "conventional" in their farming practices, since they participate in government agricultural programs and are not organic farmers. Twenty-four randomly selected farmers, most of whom operate dairy farms or grow other livestock, corn, soybeans, and/ or small grains, were asked to be inter viewed.

The second source was a list of 14 organic farmers in the southeast Michigan area, mostly in Washtenaw County, certified by Organic Farmers of Michigan (OGM), which is a nonprofit growers association. Organic farmers, for the purposes of this study, are defined as "farmers who avoid the use of any synthetic manufactured substances in growing their crops and managing their lands" (Esseks and others 1990). The farmers in this sample group grow mostly hay, small grains, fruits, vegetables, soybeans, and potatoes.

The final sample size was 25 farmers, of which 13 were conventional and 12 were organic farmers. Twentytwo of the 25 farmers interviewed had farms within Washtenaw County. The other three farmers had farms within a ten-mile radius of the county border.

Data were collected by way of personal surveys of each farmer. A survey instrument was created that combined both qualitative and quantitative methods. For the quantitative method, a group of five-point Likert-scale statements were used. In addition, openended questions were included to enhance the quantitative findings. These questions allow more freedom to the respondent in framing answers and are less encum- 
bered by a prepared set of possible replies (Weisberg and Bowen 1977, Oppenheim 1986). Following a pretest of the survey instrument, the farmers were contacted by letter to explain the study and to invite their participation. The letter was then followed by a phone call to determine agreement about being interviewed and to set-up a meeting time and place. Interviews occurred during an eight-week period in the spring season.

The survey instrument included banks of items measuring various constructs. A bank of items was included that measured environmental knowledge and attitudes including the farmers' feelings toward farmrelated environmental issues, general concern for the environment and motives for conser vation. Several of the questions were derived from the work of Napier and Camboni (1988). Another bank of items measured economic orientation and included a variety of questions about the economic risks involved in farming.

The survey instrument also included questionsabout farmers' adoption of 24 agricultural practices, essentially as a measure of conservation behavior. Twenty-one of these have been earlier identified as techniques designed to conserve soil and/or reduce synthetic fertilizer and pesticide use ( Napier and Camboni 1988, Napier and others 1988b, Bruening and Rollins 1990, Esseks and others 1990, Youngs and others 1991, Dick 1992, Anderson 1990). Three of the practices were conventional techniques often identified as contributing to soil erosion and habitat loss. Farmers' responses were constrained to six possible categories: (1) use the practice now; (2) used it in the past but not now; (3) never used it; (4) never used it but plan to; (5) the practice does not apply; and (6) unfamiliar with the practice.

For the purpose of this study it was important to determine if the two sample groups of farmers differed in their overall use of sustainable agricultural practices. Farmers' responses were therefore quantified in two ways. First, individual practices were analyzed on the basis of the percent of farmers who had adopted, or planned to adopt, that practice. These detailed data were important for comparisons with previous research and also made the overall sustainability calculations more intuitively meaningful. Based on the procedure adopted by Dick (1992), Carr and Tait (1991), and Napier and Camboni (1988), an equation was developed to calculate a farming operation's overall sustainability. O nly practices widely accepted as contributing to a farming operation's sustainability, and useful to interpret the overall scores in general terms, were included.
The calculation ( $\mathrm{CP}=$ conservation practices) was:

2(number of $C P$ used now)

+1 (number of CP already used or plan to use)

2( count of all possible $C P$ )

- 2( count of CP that were marked as inapplicable)

Points were assigned to each of the possible response categories and a score was calculated for each farmer based on the percent of applicable conservation practices used. Farmers received two points for a "use now" response, one point for a "have used" or "plan to use" response, and zero points for a "never used" or "don't know" response. Practices themselveswere not weighted, but certain practices were omitted from the overall calculation. For example, farmers' use of no-till tillage methods was not included in their overall sustainability score because some researchers have associated no-till with higher levels of herbicide use (Youngs and others 1991). Three conventional practices-fall plowing, use of moldboard plow, and use of tile drainage-were also omitted from the overall sustainability score, as were any practices that "did not apply" to a particular farming operation. The points were then totaled and divided by the total number of points possible for each individual farm. This calculation ensured that certain farmers would not be at an inherent disadvantage. For example, farmersfor whom terracing was an inappropriate conservation measure (e.g., the farm's topography did not necessitate terraces), would necessarily have received a lower score if the calculation was not based on the percent of applicable conservation practices used.

The qualitative analysis was performed in two parts: a descriptive case study of each farmer, and a cross-case interpretation of farmers' responses to each openended question, according to Patton (1990). The case study is a description of the farmer: a profile constructed from their responses and the interviewer's strong impressions of the interview as a whole. The cross-case interpretation was based on a series of categories derived from the data. The categories were created from patterns found in responses to each question, with an emphasis on indigenous concepts ( concepts specifically named by the participants, such as "enjoying being outdoors"). Categories were constructed such that they were internally homogeneous (i.e., the data in a category clearly belonged together) and externally heterogeneous (i.e., the categories were clearly different from each other) (Patton 1990). In the data analysis, concepts that were included with markedly different frequency in responses given by organic and conventional farmers and concepts that were highlyendorsed by both 
groups of farmers were reported as findings of the study.

The criteria used to determine if a markedly different number of organic and conventional farmers included a concept in responding to a question was a difference of two responses. For example, because two organic farmers cited pesticide residue on foods as a concern, and no conventional farmers cited this as a concern, the finding was reported as a difference between the two groups of farmers. A concept was considered highly endorsed by both groups of farmers if it was one of the top four most frequently mentioned concepts in responses from both groups of farmers and if at least $20 \%$ of all farmers ( 5 of 25 ) included that concept in their response.

\section{Results}

\section{Demographic and Farm Structure Profiles}

The farmers we surveyed were similar along several dimensions, including age, education, and percent of income derived from farming in 1991 (Table 1). Mean ages were 46 and 50 years for organic and conventional farmers, respectively. The typical farmer in this study had some college education, but less than a college degree. Roughly half of the income from the farm families we studied came from farming. H owever, some significant differences emerged. Conventional farmers had farmed for about twice as long as organic farmers. The findings regarding farm structure more clearly support our hypothesis that differences exist between organic and conventional farmers on this dimension. The data suggest the organic farmers typically had smaller farms (both in acreage owned and leased), with greater crop diversity than conventional farmers. For the most part, the conventional farmers studied were from a family tradition of farming, while organic farmers tended to be relatively new to farming as a profession. All 13 of the conventional farmers were from families that had almost always been involved in farming. In contrast, only three of the 12 organic farmers come from such backgrounds.

\section{Economic Orientation}

Both the qualitative and quantitative analyses indicate the two groups of farmers are concerned with economic risks. Both groups appeared at least moderately concerned about finances and also deeply concerned about farm productivity over the long term. The organic farmers seem to have an economic orientation toward farming coupled with a more long-term concern for sustainability, although their willingness to take such
Table 1. Scores on farmers' demographic characteristics

\begin{tabular}{|c|c|c|c|}
\hline Item & $\begin{array}{l}\text { Organic } \\
\text { farmers }\end{array}$ & $\begin{array}{l}\text { Conventional } \\
\text { farmers }\end{array}$ & $\begin{array}{c}\mathrm{t} \text { test } \\
\text { statistic }\end{array}$ \\
\hline Years farming & $15.5 \pm 11.5$ & $30.2 \pm 13.1$ & $\begin{array}{c}2.98 \\
d f=22.9 \\
P \leq 0.01\end{array}$ \\
\hline Acres owned & $74.1 \pm 84.6$ & $229 \pm 198$ & $\begin{array}{c}2.58 \\
d f=16.5 \\
P \leq 0.05\end{array}$ \\
\hline Acresleased & $65.0 \pm 170.5$ & $482 \pm 670$ & $\begin{array}{c}2.17 \\
d f=13.7 \\
P \leq 0.05\end{array}$ \\
\hline Age & $45.9 \pm 5.95$ & $49.7 \pm 14.2$ & NS \\
\hline Crops (N) & $6.25 \pm 2.26$ & $3.92 \pm 1.66$ & $\begin{array}{c}2.92 \\
d f=20.1 \\
P \leq 0.01\end{array}$ \\
\hline Education ${ }^{b}$ & $3.83 \pm 1.40$ & $3.54 \pm 1.90$ & NS \\
\hline $\begin{array}{l}\text { Income earned } \\
\text { from farming (\%) }\end{array}$ & $43.6 \pm 43.2$ & $58.2 \pm 30.0$ & NS \\
\hline
\end{tabular}

aScores are mean \pm SD. Twelve organic and 13 conventional farmers responded.

${ }^{\mathrm{b}} 1$ = lessthan high school, 2 = high school graduate, 3 = some college, $4=$ college graduate, $5=$ some graduate school or graduate degree, $6=$ associate degree.

risks decreased as the time period it took to gain higher yields increased. However, the organic farmers were consistently more willing to risk a reduced yield for a good chance of a higher yield in the future (Table 2). There was a similar pattern, although it missed being statistically significant, when the chances of higher yield took much longer, such as when their children would take over the farm. Organic farmers scored higher on their willingness to risk a slightly reduced yield in this season to try a new farming method designed to protect the environment. In contrast, there was no significant difference between organic and conventional farmers' responses when asked how much they think about keeping the farm productive over the long term, and both groups indicate that immediate considerations do affect their decisions about farming. Although conventional farmers show a greater concern about immediate financial considerations, the difference fails to reach statistical significance.

Several organic farmers indicated through their qualitative responses that the practices they were currently using already reflected their willingness to take risks. One organic farmer mentioned, "I think all the things I'm doing do take some time to pay off." Likewise, several organic farmers mentioned that terms such as "profit" and "yield" were not appropriate to their farming decisions per se. Thus, even though the organic farmers as a group indicated their overall concern for financial considerations, for some of these 
Table 4. Scores on farmers'

environmental awareness ${ }^{a}$

\begin{tabular}{|c|c|c|c|}
\hline Item & $\begin{array}{l}\text { Organic } \\
\text { farmers }\end{array}$ & $\begin{array}{l}\text { Conventional } \\
\text { farmers }\end{array}$ & $\begin{array}{c}\mathrm{t} \text { test } \\
\text { statistic }\end{array}$ \\
\hline $\begin{array}{l}\text { Farmers' decisions } \\
\text { can have an } \\
\text { important effect on } \\
\text { the environment }\end{array}$ & $4.83 \pm 0.39$ & $4.69 \pm 0.48$ & \\
\hline $\begin{array}{l}\text { Agricultural pollution } \\
\text { is a serious } \\
\text { environmental } \\
\text { problem }\end{array}$ & $4.33 \pm 0.89$ & $3.54 \pm 1.39$ & $\begin{array}{c}1.72 \\
d f=20.6 \\
P \leq 0.10\end{array}$ \\
\hline $\begin{array}{l}\text { Agricultural pollution } \\
\text { is a serious threat to } \\
\text { human health }\end{array}$ & $4.50 \pm 0.90$ & $3.23 \pm 1.3$ & $\begin{array}{c}2.85 \\
d f=21.4 \\
P \leq 0.01\end{array}$ \\
\hline $\begin{array}{l}\text { Soil erosion is a } \\
\text { serious problem in } \\
\text { the United States }\end{array}$ & $4.58 \pm 0.79$ & $4.08 \pm 1.19$ & \\
\hline $\begin{array}{l}\text { Soil erosion is a } \\
\text { serious problem on } \\
\text { your farm }\end{array}$ & $1.83 \pm 0.94$ & $1.85 \pm 0.90$ & \\
\hline $\begin{array}{l}\text { Pollution from the use } \\
\text { of agricultural } \\
\text { chemicals is a } \\
\text { serious problem in } \\
\text { the United States }\end{array}$ & $4.50 \pm 0.52$ & $3.77 \pm 1.48$ & $\begin{array}{c}1.67 \\
d f=15.2 \\
P \leq 0.10\end{array}$ \\
\hline $\begin{array}{l}\text { Pollution from the use } \\
\text { of agricultural } \\
\text { chemicalsis a } \\
\text { serious problem on } \\
\text { your farm }\end{array}$ & $1.17 \pm 0.39$ & $2.54 \pm 1.45$ & $\begin{array}{c}3.28 \\
d f=13.9 \\
P \leq 0.006\end{array}$ \\
\hline
\end{tabular}

${ }^{a} 1=$ strongly disagree, 2 = agree, $3=$ neutral, $4=$ agree, $5=$ strongly agree. Twelve organic and 13 conventional farmers responded.

farmers. Again, the findings on this hypothesis were mixed. Indeed, several significant trends emerged in comparing the mean scores of environmental awareness between organic and conventional farmers (Table 4). Both groups had statistically identical high scores with regard to their feeling that farmers' decisions can have an important effect on the environment. This result suggests that both organic and conventional farmers see themselves as the actor or agent of change with regard to their decisions' effects on the environment. However, organic and conventional farmers differed with regard to their awareness of agricultural pollution as a serious environmental problem as well as a serious threat to human health; organic farmers scored higher on both of these items, indicating a higher degree of concern. Both groups equally viewed soil erosion as more of a problem in the United States, but not on their individual farms.

Organic farmers were more aware of and concerned about agricultural chemical pollution than were conventional farmers (Table 5). Both groups scored lower (i.e., means were below 3.0) in terms of viewing pollution
Table 5. Farmers' agricultural pollution concerns ${ }^{a}$

\begin{tabular}{lcc}
\hline $\begin{array}{l}\text { If you think agricultural } \\
\text { pollution is a problem, } \\
\text { what most concerns you? }\end{array}$ & $\begin{array}{c}\text { Organic } \\
\text { farmers (\%) }\end{array}$ & $\begin{array}{c}\text { Conventional } \\
\text { farmers (\%) }\end{array}$ \\
\hline $\begin{array}{l}\text { Agricultural chemicals } \\
\text { Pesticide residues on food }\end{array}$ & 75 & 50 \\
Air pollution/ Pesticide drift & 17 & 0 \\
Lack of control over problem & 17 & 0 \\
Effect of chemicals on entire & 17 & 0 \\
$\quad$ & 33 & 17 \\
$\quad$ ecosystems & 0 & 25 \\
Surface water pollution & 0 & 42 \\
Mot a problem & & \\
$\quad$ farmers & & 63 \\
$\quad \begin{array}{c}\text { Agricultural chemicals } \\
\text { Water pollution of some type }\end{array}$ & & 46 \\
Human health & & 38 \\
Groundwater pollution & & 25 \\
\hline
\end{tabular}

$\mathrm{a} N=12$ for organic farmers and $\mathrm{N}=13$ for conventional farmers.

from the use of agricultural chemicals as a serious problem on their particular farms. There was a significant difference in their responses, however, with conventional farmers viewing such pollution from agricultural chemicals as more of a problem than organic farmers. However, the mean of the conventional farmers' responses does indicate their tendency not to view such chemical pollution as a serious problem on their farm or to be neutral on that point.

Further evidence of this concern for pollution was shown in the qualitative responses. In response to the question, "If you think agricultural pollution is a problem, what most concerns you?" nearly all responses from both groups of farmers involved the effects of agricultural chemical use (Table 5). Only $8 \%$ of all farmers were concerned about soil erosion as a form of agricultural pollution. However, three fourths of organic and one half of conventional farmers mentioned agricultural chemicals in their responses. Organic and conventional farmers were both concerned about the human health effects of agrochemical use; nine of the 25 felt this was a problem. Specifically, about half of all farmers were concerned about water pollution of some form, and organic and conventional farmers were equally concerned about groundwater pollution, although only a fourth of them mentioned this concern.

While most farmers from both groups were concerned about the use of agricultural chemicals, a considerable number of conventional farmers indicated that agricultural pollution was not a problem. In response to the question, these farmers spoke of the pollution associated with industrial and residential areasand golf courses as their main concerns. In addition, apart from their common concern with groundwater 
pollution and human health, organic and conventional farmers disagreed about the specific effects of agricultural chemical use. For example, $25 \%$ of conventional farmers mentioned pollution of surface water as a major concern, while none of the organic farmers referred to surface water pollution. In contrast, $33 \%$ of the organic growers were concerned with the effects of agricultural chemicals on the entire ecosystem, while only $17 \%$ of the conventional farmers expressed this concern. O rganic farmers also expressed concern about pesticide residues on food, air pollution, pesticide drift, and their lack of control over the problem. N one of the conventional farmers included these concerns in their responses.

With regards to measures of success in farming in relation to economic orientation, respondents also indicated an affinity for the environment. The most common response to this question among organic farmers was "improving the quality of the soil." Soil was mentioned specifically by five of the organic farmers, who mentioned taking the soil as the key to the health, vitality, and sustainability of the land. None of the conventional farmers mentioned soil. Three of the organic farmers reported "personal satisfaction" and/ or providing a "healthy product" as measures of success. When asked what they would miss most if they had to leave their farms, many lay emphasis on nature and less on individual actions as a farmer. Nature was the most frequently occurring concept in responsesfrom organic and conventional farmers and was said with almost equal frequency by both groups.

\section{Agricultural Practices of Farmers}

It was hypothesized that conventional farmers would report using conservation practices with less frequency than organic farmers. Several patterns emerged in this regard (Table 6). Organic and conventional farmers did not differ significantly with regard to their use of crop rotations, mulch or ridge tilling, moldboard plows, and grassed water ways. H owever, far more conventional farmers used no-till as a conservation practice. Although similar proportions of organic and conventional farmers used grassed waterways, half of the organic farmers responded that grassed water ways were not applicable to their farms, compared with about one third of the conventional farmers. A far larger proportion of organic farmers used green manures, winter cover crops, and windbreaks. Conventional farmers reported more removal of windbreaks and hedgerows. They also used soil tests to a greater extent and, in the interviews, most of these farmers reported that soil tests are done by chemical fertilizer dealers.

Based on an overall score for the use of conser vation
Table 6. Farmers adopting selected

conservation practices ${ }^{a}$

\begin{tabular}{|c|c|c|}
\hline Item & $\begin{array}{c}\text { Organic } \\
\text { farmers (\%) }\end{array}$ & $\begin{array}{l}\text { Conventional } \\
\text { farmers (\%) }\end{array}$ \\
\hline \multicolumn{3}{|l|}{ Crop rotations } \\
\hline Crop rotations with legume & 92 & 77 \\
\hline Crop rotations without legume & 8 & 8 \\
\hline \multicolumn{3}{|l|}{ Hedgerows/ tree windbreaks } \\
\hline \multicolumn{3}{|l|}{ Put in or maintain } \\
\hline hedgerows/ windbreaks & 83 & 38 \\
\hline \multicolumn{3}{|l|}{ Removed } \\
\hline hedgerows/ windbreaks & 0 & 23 \\
\hline No hedgerows/ windbreaks & 8 & 54 \\
\hline \multicolumn{3}{|l|}{ Plan to put in } \\
\hline hedgerows/ windbreaks & 8 & 8 \\
\hline \multicolumn{3}{|l|}{ Tillage } \\
\hline Mulch (chisel) or ridge till & 42 & 54 \\
\hline Moldboard plow & 75 & 85 \\
\hline No till & 8 & 31 \\
\hline \multicolumn{3}{|l|}{ Grassed water ways } \\
\hline Use now & 42 & 38 \\
\hline Do not use now & 8 & 31 \\
\hline Does not apply & 50 & 31 \\
\hline \multicolumn{3}{|l|}{ Green manure } \\
\hline Use now & 92 & 54 \\
\hline Do not use now & 8 & 46 \\
\hline Does not apply & 0 & 0 \\
\hline \multicolumn{3}{|l|}{ Soil testing } \\
\hline Use now & 42 & 92 \\
\hline Do not use now & 58 & 8 \\
\hline Does not apply & 0 & 0 \\
\hline \multicolumn{3}{|l|}{ Winter cover crops } \\
\hline Use now & 83 & 54 \\
\hline Do not use now & 17 & 46 \\
\hline Does not apply & 0 & 0 \\
\hline
\end{tabular}

${ }^{a} \mathrm{~N}=12$ for organic farmers and $\mathrm{N}=13$ for conventional farmers.

practices, organic farmers scored much higher than the conventional farmers. Despite this difference, the two groups of farmers nevertheless indicate a fairly high rate of applicable conservation practices. On average, organic farmers adopted $75.5 \%$ of the conservation practices applicable to their farming operations, while conventional farmers adopted only $57.5 \%$ of applicable conservation practices. On the one hand, organic farmers had in general adopted a greater number of both soil conservation and reduced chemical practices than conventional farmers. On the other hand, the only practices conventional farmers had adopted at a higher rate than organic farmers were soil testing and conser vation tillage-especially no-till. Thus, if no-till was the only criterion used for sustainability, the organic farmers in this study would not be considered sustainable. H owever, using broader criteria, including a variety of practices that contribute to the sustainability of a farming operation, organic farmers were shown to be farming considerably more sustainably than their con- 
ventional counterparts. These findings, therefore, support the original hypothesis that organic farmers would, in general, use conservation practices with greater frequency than conventional farmers.

While organic and conventional farmers varied significantly in their adoption of conservation practices, they shared a common concern for the environmental impact of agriculture. Both groups of farmers agreed through the inter views that farmers' decisions can have an important effect on the environment ( organic $=4.83$; conventional $=4.69$ ). For organic farmers, this concern was clearly manifested in their adoption of sustainable agriculture practices. For conventional farmers, however, the concern seems not to directly influence their behavior.

\section{Discussion}

Although further studies, with larger sample sizes, would be needed to gain a more in-depth understanding of the interactions of farmers' conservation attitudes and behaviors, several interesting trends have emerged. The farmers inter viewed here are similar in many ways, but different in some important respects. They are independent people with multiple motives for conservation.

$O$ ver the past 50 years, the farm population has been radically changed from a relatively homogeneous group of small- and medium-sized diverse family farms to much larger and specialized operations ( Constance and others 1990, Albrecht and Murdock 1990, Strange 1988). The nation is also seeing an exodus of young people leaving their small- and medium-sized family farms as the economic risks of farming continue to grow. When operating smaller family farms is no longer of interest to the next generation, the land almost always goes to a bigger farmer with the machinery, powerful chemical inputs, and capital to make such land profitable. Likewise, as Constance and others (1990) point out, the historical farming problems of excess supply, and their associated problems of low prices and unstable incomes, have shifted to problems of increased financial risk from incurred debt, product price instability, high inflation from input costs, and concentrated input and product markets. Consequently, farmers are faced with a variety of difficult decisions, coupled with a need to understand and adapt to the rapid changes inherent in modern agriculture.

Peterson (1991) discussed how difficult it is for farmers to make sound decisions given conflicting priorities and overwhelming constraints. Many of the conventional farmers interviewed for this study are quite literally tied to the land. Many love, respect, and understand nature, but they also feel a pressing obligation to preserve the economic operation that has provided the format for this knowledge. These conflicting motives may result in what Peterson (1991) called a fundamentally dysfunctional perspective toward conservation. The conventional farmers perceive themselves as people of the land, yet they frequently sacrifice its health in the interest of continued farming. While the farmers inter viewed here are certainly not representative of all the nation's farmers, it seems clear from the results that the dichotomy of paradigms outlined above is complex. The conventional farmers inter viewed did not measure everything in terms of production efficiency and profit generation, nor did the organic farmers care simply about environmental protection. Indeed, both groups of farmers were simultaneously concerned with economics and the health of the land.

This study supports the findings of Napier and others (1988a,b) and Buttel and others (1981), which identify the importance of economics in farmers' decisions. Farmers are typically proud of their products and frustrated by the inadequate financial reward they receive for their efforts. Both organic and conventional producers function as independent farm operators, wholly dependent on an economic structure largely beyond their control. In addition, both groups are concerned with the long-term productivity of their farms. While the organic farmers' short-term profits are tied to their methods of farming ( dependent on marketing certified organic products), the conventional farmers' ability to keep their farms from year to year is based primarily on yield. The organic farmers may seek to make a greater profit by improving their short-term yield, but the methods to achieve short-term success would rarely preclude, and would most likely enhance, the long-term productivity of their land. The conventional farmers have different methods at their disposal, including many that might trade the long-term productivity and health of the land for short-term reward. Because the main concern is with keeping the farm, this trade-off is frequently ir resistible.

Although the conventional and organic farmers studied did not differ with regard to the percent of their incomes derived from farming, their differences in land tenure patterns, as well as general attitudes about the financial rewards and limitations of farming, suggest that they may have different economic pressures affecting their decisions. While both groups are concerned with economics, the conventional farmers may have more or different financial debts to consider than the organic farmers. Several of the conventional farmers, who tended to have more acreage and lease more land, mentioned the financial burdens accompanying their 
farming businesses. One mentioned that he hoped this year he would, ". . . make enough [money] to make the farm payments, repair some machinery, and [pay his] living expenses." These findings are consistent with the notion of Buttel and others (1981) that higher debt burdens combined with a largely economic orientation toward agriculture make large farms less likely to be concerned with and adopt practices to protect the environment.

Another difference in the farmers' economic orientation and farming practices involves different perceptions regarding their ability to successfully adopt more sustainable practices. Given that only one farmer interviewed was making the transition from conventional to sustainable agricultural practices, a telling statement from a conventional farmer was that he "knew a lot of farmers in the area that all went bankrupt when they tried that LISA [Low Input Sustainable Agriculture] thing." This statement may indicate that people whose initial purpose is to farm organically from the start do so with less economic burden and risk than more conventional farmers who try to make such a transition later in their farming careers. Likewise, conventional farmers may view the economic risks of adopting such practices as too great. These concerns are echoed in the conventional responses to several of this study's "economic orientation" questions. Although these farmers showed some willingness to adopt conser vation practicesand/ or risk a reduced yield this season to try a farming method to protect the environment, their willingness was significantly less than that of the organic farmers. On a positive note, the data do suggest that both organic and conventional farmers are willing to try new farming methods to protect the environment and are willing to take at least a minimal risk to try new conservation practices.

The conventional farmers in this study were from families that have been involved in farming over several generations. In contrast, the organic farmers surveyed were most often the first generation of farmers in their families. These organic farmers scored far higher in terms of the overall sustainability of their agricultural practices, as well as in terms of using green manure, planting winter cover crops, maintaining hedgerows, and using crop rotations with legumes. In addition to the organic farmers' tendency to currently utilize more sustainable agricultural practices, they also appeared to have a greater general concern for the land's long-term sustainability. For a variety of reasons it may be appropriate to encourage and protect farms managed by successive generations over time. In addition, though, if environmental protection is a main concern, there might be value in encouraging new people into farming.

The results of the present study regarding environmental awareness suggest that government programs do seem to be somewhat effective as an educational tool. This trend is particularly true with regard to soil erosion. The current findings indicate that governmental programs to increase awareness about soil erosion at the national level have been effective among this sample. Both the organic and conventional farmers tended to understand this issue. The farmers' general concern about soil erosion nationwide indicates a high level of awareness. Expanding on these findings, one can speculate that more programs should be implemented to increase farmers' knowledge about other environmental problems associated with farming. This need to increase awareness and support alternative practices to protect the environment is particularly appropriate with regard to agricultural chemical use. In their quantitative and qualitative responses, both organic and conventional farmers indicated at least a minimal concern about agricultural chemical use. These concerns, coupled with these farmers' seeming willingness to try agricultural practices designed to protect the environment, suggest that more programs designed to increase awareness about agricultural problems and solutions might be effective.

The findings reported here suggest that farms of smaller acreage and greater crop diversity might be encouraged if more sustainable practices are to be successfully ad opted. However, some research supports the theory that larger farms have more resources and are therefore more able to take economic risks, which includes the risk of experimenting with different (and potentially more sustainable) agricultural practices (Esseks and others 1990). Another argument is that larger farms are focused on short-term financial gain and less willing to take risks, particularly those that take some time to pay off (Buttel and others 1981). The findings of the present study are consistent with this second argument. The results indicate that while both groups showed a willingness to take risks to keep their farms productive over the long term, and/ or protect the environment, this willingness decreased for the farmers of larger farms as the time for such risks to pay off increased. O ne could therefore argue that farm structure can affect a farmers' willingness to adopt more sustainable farming practices.

This study illustrates the caution researchers should exercise in designing instruments to measure sustainability. First, in our sample, more than twice as many conventional as organic farmers test their soil regularly. On the surface, this may seem to indicate a greater 
sensitivity to soil fertility on the part of the conventional sample. Through the inter views, however, it was learned that most conventional farmers have their soil tested by chemical fertilizer dealerships, which provide testing along with-and frequently as an incentive to buychemical products. Organic farmers may not be as concerned about soil monitoring if they place high priority on improving soil quality, assess it through plant-growth indicators, and are doing all they can to avoid degrading it. Soil testing may seem superfluous to them. Second, the calculation of an aggregate score of sustainability is somewhat biased toward use of multiple conservation practices currently in use. In future studies, consideration should be given to the spatial extent of a particular conservation practice or to the interactive effects of multiple conservation practices.

This research points toward several areas where further work should be done. A spectrum of farmers, including absentee, conventional, organic, and corporate farmers, as well as farmers who are in the transition phase to more sustainable methods, should be studied using a variety of conservation measures to determine if there are valid differences among such farmers with respect to their conservation behavior. Further research with a larger, more diverse sample can build on these findings to gain a clearer understanding of the complexities inherent in modern agriculture.

Given the numerous and severe environmental consequences of modern agriculture, it is essential that producers who farm sustainably continue their practices and that more producers be encouraged to adopt conservation practices. Farmers are not a homogeneous group. They perceive and react differently to conservation issues, and their attitudes regarding the control of environmental problems vary. Therefore, an understanding of farmers' attitudes and behaviors regarding conservation is vital for the identification and implementation of effective conservation measures.

\section{Acknowledgments}

The authors appreciate the insightful comments of the 24 farmers who were interviewed for this study and two anonymous reviewers who gave valuable comments on an earlier version of this paper. This research was funded by the University of Michigan School of $\mathrm{N}$ atural Resources and Environment.

\section{Literature Cited}

Albrecht, D. E., and S. H. Murdock. 1990. The sociology of U.S. agriculture: An ecological perspective. Iowa State University Press, Ames, Iowa.
Anderson, M. 1990. Farming with reduced synthetic chemicals in North Carolina. American Journal of Alternative Agriculture 5:60-68.

Bruening, T. H., and T. J. Rollins. 1990. Perceptions of Pennsylvania farm operators regarding selected soil and water conservation practices. Department of Agricultural and Extension Education, The Pennsylvania State University, University Park, Pennsylvania.

Bultena, G. L., and E. O. Hoiberg. 1983. Factors affecting farmers' adoption of conservation tillage. Journal of Soil and Water Conservation 38:281-283.

Bultena, G., P. Nowak, E. Hoiberg, and D. Albrecht. 1981. Farmers' attitudes toward land use planning. Journal of Soil and Water Conservation 36:37-41.

Buttel, F. H., G. W. Gillespie, Jr., O. W. Larson, III, and C. K. $\mathrm{H}$ arris. 1981. The social bases of agrarian environmentalism: A comparative analysis of New York and Michigan farm operators. Rural Sociology 46:391-410.

Carr, S., and J. Tait. 1991. Differences in the attitudes of farmers and conser vationists and their implications. Journal of Environ mental M anagement 32:281-294.

Christensen, L. A., and P. E. Norris. 1983. Soil conservation and water quality improvement: What farmers think. Jou rnal of Soil and Water Conservation 38:15-20.

Constance, D. H., J. L. Gilles, and W. D. Heffernan. 1990. Agrarian policies and agricultural systems in the United States. Pages 9-75 in A. Bonanno (ed.), Agrarian policies and agricultural systems. Westview Press, Boulder, Colorado.

Dick, R. 1992. Sustainability, can it be measured in agricultural systems? Proceedings of the Fourth N orth American Symposium on Society and Resource Management, 18 May 1992. Madison, Wisconsin.

Duff, S. N., D. P. Stonehouse, S. G. H ilts, and D. J. Blackburn. 1991. Soil conservation behavior and attitudes among Ontario farmers toward alternative government policy responses. Journal of Soil and Water Conservation 46:215-219.

Esseks, J. D., S. E. Kraft, and L. K. Vinis. 1990. Agriculture and the environment: A study of farmers' practices and perceptions. Report of The American Farmland Trust, Washington, DC, $24 \mathrm{pp}$.

Hoover, H., and R. Oscar. 1980. Farmer participation in the $\mathrm{H}$ all County ACP special water quality project, Nebraska, 1980. Staff Report. No. AG-ES820319. Washington, DC.

Jacobsen, R. M., G. A. Youngs, Jr., G. A. Goreham, D. L. Watt, B. L. Dahl, R. S. Sell, and L. D. Stearns. 1991. Selected characteristics of North Dakota farm families engaged in sustainable agriculture practices. Agricultural Economics Report No. 271. Department of Agricultural Economics, North Dakota State University.

L ockeretz, W. 1988. O pen questions in sustainable agriculture. A merican Journal of Alternative A griculture 3:174-181.

Lockeretz, W. 1992. Methodological and conceptual issues in examining the adoption of resource management practices. Proceedings of the Fourth North American Symposium on Society and Resource Management, 18 May, 1992. Madison, Wisconsin.

Miranowski, J. A. 1982. O verlooked variables in BMP implementation: Risk, attitudes, perceptions and human capital characteristics. In Perceptions, attitudes and risk: Overlooked 
variables in formulating public policy on soil conservation and water quality. Staff Report No. AGES 820129. Economic Research Service, US Department of Agriculture, Athens, Georgia.

Napier, T. L., and S. M. Camboni. 1988. Attitudes toward a proposed soil conservation program. Journal of Soil and Water Conservation 43:186-191.

Napier, T. L., and D. L. Forster. 1982. Farmer attitude and behavior associated with soil erosion control. In H. G. Halcrow, E. O. Heady, and M. L. Cotner (eds.), Soil conservation policies, institutions and incentives. Soil Conservation Society of America, Ankeny, I owa.

Napier, T. L., C. S. Thraen, and S. L. McClaskie. 1988a. Adoption of soil conservation practices by farmersin erosionprone areas of Ohio: The application of logit modeling. Society and N atural Resou rces 1:109-107.

Napier, T. L., C. S. Thraen and S. M. Camboni. 1988b. Willingness of land operators to participate in governmentsponsored soil erosion control programs. Journal of Rural Studies 4:339-347.

National Research Council. 1989. Alternative agriculture. National Academy Press, Washington, DC, 448 pp.

Nowak, P. 1992. The USDA national water quality demonstration projects. Proceedings of the Fourth North American Symposium on Society and Resource Management, 18 May 1992. Madison, Wisconsin.

Oppenheim, A. N. 1986. Questionnaire design and attitude measurement. Gower Publishing Company, London.
Patton, M. Q. 1990. Qualitative evaluation and research methods. Sage Publications, N ewbury Park, California, 532 pp.

Peterson, T. R. 1991. Telling the farmers' story: Competing responses to soil conservation rhetoric. Quarterly Journal of Speech 77:289-308.

Rogers, E. M. 1983. Diffusion of innovations. The Free Press of Glencoe, New York.

Schaefer, P. R. 1989. Trees and sustainable agriculture. American Journal of Alternative A griculture 4:173-179.

Sell, R. S., B. L. Dahl, G. A. Goreham, R. M. Jacobsen, L. D. Stearns, D. L. Watt, and G. A. Youngs Jr. 1991. Sustainable agriculture and the structure of North Dakota agriculture. Agricultural Economics Report No. 274. Department of Agricultural Economics, North Dakota State University, Fargo.

Strange, M. 1988. Family farming: a new economic vision. The Institute for Food and Development Policy, San Francisco.

Tremblay, K. R., and R. E. Dunlap. 1978. Rural-urban residence and concern with environmental quality: A replication and extension. Rural Sociology 43:474-491.

Weisberg, H. F., and B. D. Bowen. 1977. An introduction to survey research and data analysis. W. H. Freeman and Company, San Francisco.

Westmacott, R. 1983. The Conser vation of farmed landscapes: Attitudes and problems in the United States and Britain. L andscape Design August:11-14.

Youngs, G. A., Jr., G. A. Goreham, and D. L. Watt. 1991. Classifying conventional and sustainable farmers: Does it matter how you measure? Journal of Sustainable Agriculture 2:91-115. 